\title{
Use of Vacuum-suction in Depressed Skull Fractures - Case Report and Technical Nuances of Nonoperative Treatment
}

\section{Uso da vácuo-sucção nas fraturas em afundamento - Relato de caso e aspectos técnicos do tratamento não-operatório}

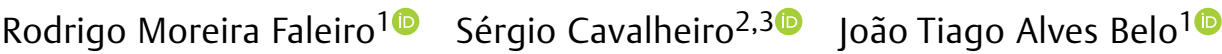

Vítor Vieira de Souza Moraes ${ }^{10}$ Aieska Kellen Dantas dos Santos ${ }^{10}$ Ellano de Brito Pontes ${ }^{10}$

Rodrigo de Oliveira Teixeira ${ }^{4}$ Aretha Miranda Silva ${ }^{3 \odot} \quad$ Nathalia Lacerda Eller Costa ${ }^{3(0)}$

1 Department of Neurosurgery, Hospital Felício Rocho e Hospital de

Address for correspondence Vítor Vieira de Souza Moraes, MD, Departamento de Neurocirurgia, Hospital Felício Rocho, Avenida

Pronto-Socorro João XXIII , Belo Horizonte, MG, Brazil

2 Department of Neurosurgery, Universidade Federal de São Paulo, Contorno, 9530-Barro Preto, Belo Horizonte, MG, 30110-934, Brazil São Paulo, SP, Brazil

${ }^{3}$ Department of Neurosurgery, Faculdade Ciências Médicas de Minas (e-mail: vieirafcmmg@gmail.com).

Gerais, Belo Horizonte, MG, Brazil

${ }^{4}$ Department of Nuclear Engineering, Instituto Militar de Engenharia, Rio de Janeiro, RJ, Brazil

Arq Bras Neurocir 2021;40(3):e263-e267.
Abstract
Keywords
- neurosurgery
- pediatric neurosurgery
- skull fractures
- depressed skull fractures
- vacuum-suction

\section{Resumo \\ Palavras chave \\ - neurocirurgia \\ - neurocirurgia pediátrica \\ - fratura craniana \\ - fratura em afundamento \\ - vácuo sucção}

Up to $20 \%$ of victims from skull fractures are represented by the pediatric population, and $50 \%$ of these lesions are depressed skull fractures. The treatment is multimodal in nature, ranging from conservative treatment to open surgical repair. The last one is associated, although in a small proportion, to complications, such as infections, hematomas and even death, besides the risks of the anesthetic procedure itself. The authors of the present article present a case report of the successful treatment of a depressed skull fracture in a newborn patient, using the vacuum-suction technique. The use of vacuum-suction may be beneficial for the pediatric patients, as it is a quick, non-invasive procedure, without the need for general anesthesia.

Até $20 \%$ das vítimas de fraturas de crânio são representadas pela população pediátrica, e $50 \%$ dessas lesões são fraturas em afundamento. O tratamento é multimodal, que vai desde o conservador até a correção cirúrgica aberta da falha óssea. O último é associado, embora em uma pequena proporção, a complicações como infecções, hematomas e até mesmo óbito, além dos riscos inerentes ao procedimento anestésico por si só. Os autores do presente artigo apresentam um relato de caso do tratamento bem sucedido de uma fratura em afundamento em um paciente recém-nascido, com o uso da técnica de vácuo-sucção. $O$ uso da técnica de vácuo-sucção pode ser benéfico para os pacientes pediátricos pelo fato de ser um procedimento rápido, não invasivo e sem necessidade do uso de anestesia geral. received

April 22, 2020

accepted

August 5, 2020

published online

October 16, 2020
DOI https://doi.org/ 10.1055/s-0040-1718423. ISSN 0103-5355.

\footnotetext{
(c) 2020. Sociedade Brasileira de Neurocirurgia. All rights reserved. This is an open access article published by Thieme under the terms of the Creative Commons Attribution-NonDerivative-NonCommercial-License, permitting copying and reproduction so long as the original work is given appropriate credit. Contents may not be used for commercial purposes, or adapted, remixed, transformed or built upon. (https://creativecommons.org/ licenses/by-nc-nd/4.0/)

Thieme Revinter Publicações Ltda., Rua do Matoso 170, Rio de Janeiro, RJ, CEP 20270-135, Brazil
} 


\section{Introduction}

Depressed skull fractures are an entity often associated with high kinetic energy trauma, leading to misalignment of the skull bone fragments from their original position. ${ }^{1,2}$ Up to $20 \%$ of the patients with skull fractures are represented by the pediatric population, and it is noteworthy that in half of these cases, the type of injury is characterized by a depressed fracture. In this age group, especially in young children, this entity is associated with obstetric trauma, falls and physical injury. $^{3}$

The treatment of depressed skull fractures is multimodal in nature, ranging from conservative treatment, with clinical observation and expectation of spontaneous fracture reduction, to surgical procedures to correct the bone defect. ${ }^{3-6}$ The authors present a case report of the correction of a depressed skull fracture in a pediatric patient, using the physical principles of vacuum suction, described through the vectors applied over the skull, and its benefits.

\section{Case Report}

A newborn patient suffered a head injury during labor. She didn't evolve with any neurological complications, but was immediately submitted to a cranial computed tomography (CT) scan, after a skull defect was detected on physical examination (-Fig. 1). She was diagnosed with a depressed skull fracture, being referred to a neurological surgeon after hospital discharge. The CTscan ( - Fig. 2) shows a depressed right frontal bone fracture, with no underlying brain injuries. Interventional treatment was indicated to avoid future complications, such as seizures, and for cosmetic reasons. Nonsurgical treatment was chosen, considering its possible complications, especially in young children. Elevation of the depressed skull fracture was made using a vacuum extractor (pediatric oxygen mask, connected to a vacuum source). The procedure was conducted

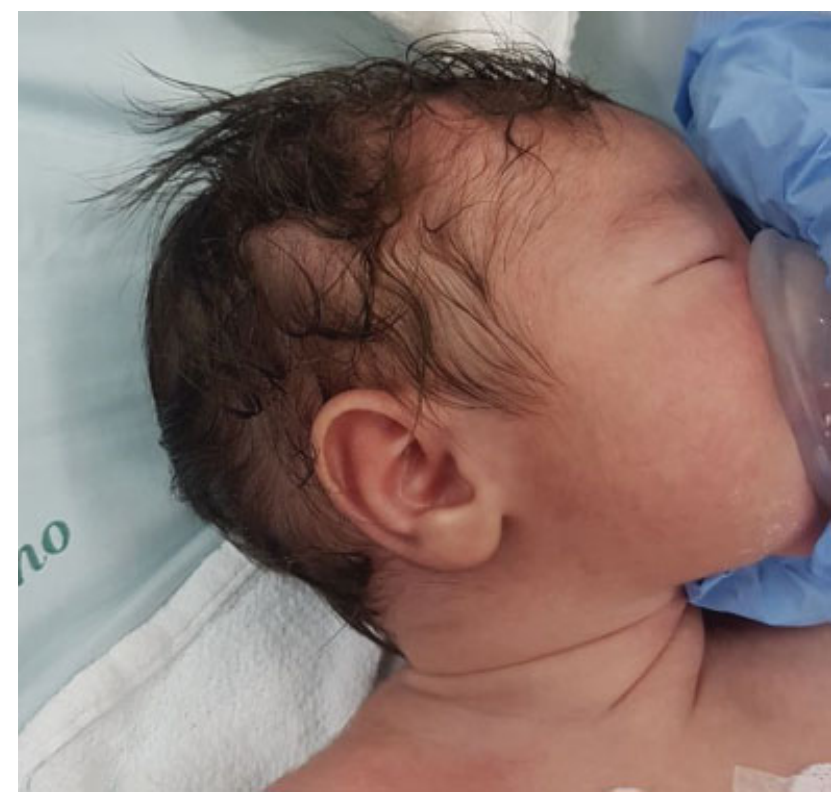

Fig. 1 Depressed skull fracture - physical Exam. under sedation and lasted $\sim 15$ minutes. No complications occurred in the postprocedural period. Postoperative CT scan shows adequate resolution of depressed skull fracture (-Fig. 3). Note: the patient's parents agreed with the publication of the images submitted in the present article, for scientific purposes only, without any form of identification through the subject's name or hospital records.

\section{Discussion - Treatment Modalities}

Depressed skull fractures, by definition, are caused by relatively high kinetic energy traumas, capable of promoting displacement of bone fragments toward the interior of the skull. ${ }^{1,3-5}$ In this specific lesion, the largest area of bone depression may be located at or adjacent to the fracture interface and the intact cranial surface, when multiple fragments are displaced perpendicular to the cranial surface. ${ }^{1,3,7}$ Ping pong fracture is a special type of depressed fracture, commonly found in neonates and young children, who are victims of low kinetic brain injury. ${ }^{8,9}$ In such cases, a skull bone depression occurs, without necessarily demonstrating a fracture line in radiological studies, similar to a greenstick fracture. It occurs mainly due to the smaller thickness and density, and greater resilience of bone tissue in this population, and is rarely associated with intracranial lesions. ${ }^{10}$

In $25 \%$ of the cases, patients do not have any focal deficits or other neurological complications, such as an altered level of consciousness or seizures. Another 25\% may have only a brief loss of consciousness. However, in a large number of cases, surgical treatment is indicated, for several purposes: relief of pressure on the underlying brain parenchyma, at the fracture location (with subsequent increase in cortical blood flow), reduction of the risk of future epilepsy, correction of cosmetic deformities and prevention of infection (in open fractures). ${ }^{3,11,12}$

The standard treatment for depressed skull fractures is the surgical elevation of bone fragments back to their normal position. The procedure is indicated when the area of bone depression is larger than the full thickness of the affected bone. In simple depressed fractures, without injury to the dura and underlying parenchyma, surgical treatment is brief, based on exposure of the bone defect and deformity correction. In cases where there are dural lesions and injury to the brain parenchyma, as well as gross contamination (in open fractures), it is imperative to perform more aggressive treatment, with debridement of devitalized tissues, hemostasis and hermetic closure of the dura mater. ${ }^{3,13,14}$

\section{Discussion - Physical Aspects}

It is important to describe the physical aspects that are responsible for the success of the vacuum-suction procedure in the treatment of depressed skull fractures. First, to understand the concept of vacuum, created within the dome of the object, applied over the skull, it is necessary to understand the concept of pressure.

Pressure is known to be a physical quantity that measures how much force is being exerted per unit area. The unit of 


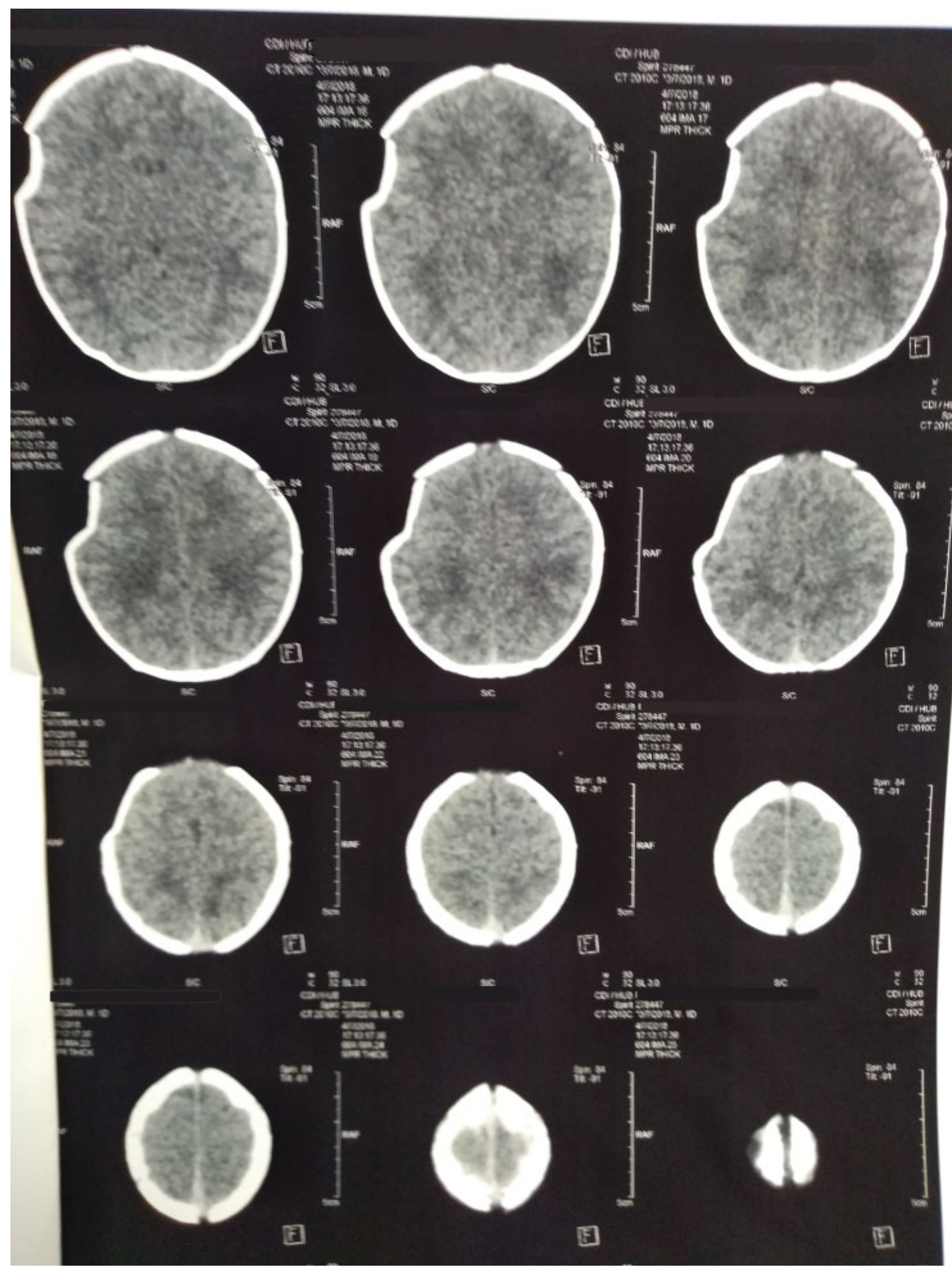

Fig. 2 Computed tomography scan of the head - preprocedure.

measure used in the international system is newton/meter ${ }^{2}$ $\left(\mathrm{N} / \mathrm{m}^{2}\right)$, which is related to atmospheric pressure. The value of $1 \mathrm{~atm}$ represents the action of the weight of the atmospheric air layer (force weight) per unit surface area of the earth at sea level (atmospheric pressure reference). The ratio between these two units is $1 \mathrm{~atm}=100,000 \mathrm{~N} / \mathrm{m}^{2}$. Consider- ing the gravitational acceleration of the Earth close to $9.8 \mathrm{~m} /$ $\mathrm{s}^{2}$, for each $1 \mathrm{~m}^{2}$ of area (the average human body has an area of $1.90 \mathrm{~m}^{2}$ for men and $1.6 \mathrm{~m}^{2}$ for women), the human being is subjected to an atmospheric pressure equivalent to the weight created by a mass of 10 tons. ${ }^{15}$ The reason our body is not overwhelmed by the action of the earth's atmosphere is 


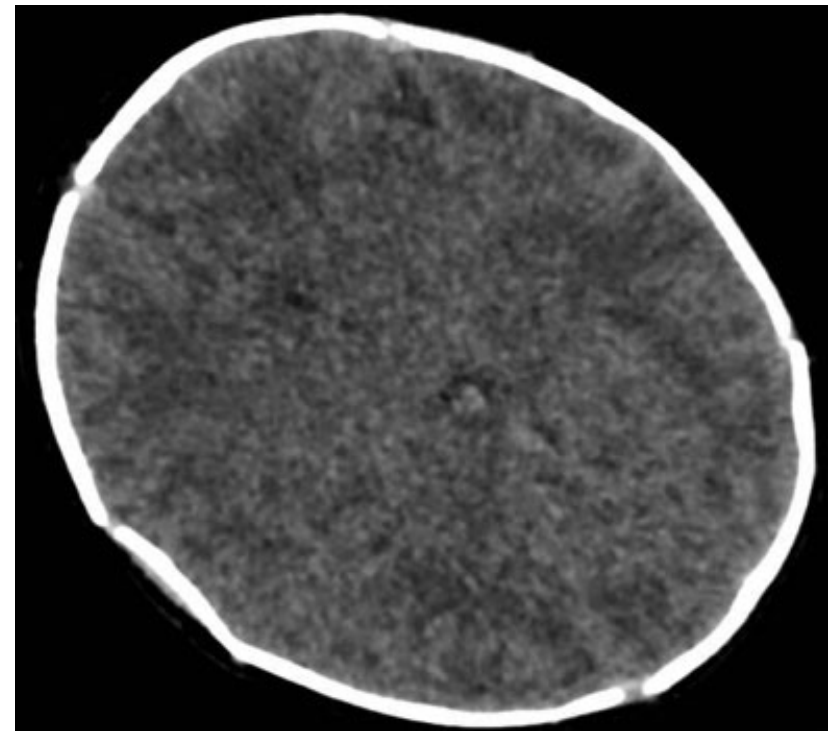

Fig. 3 Computed tomography scan of the head - postprocedure.

that we have an internal body pressure that balances with the external pressure of the atmosphere, as with an open container completely filled with air. Therefore, the internal pressure of the object, and the external pressure of the atmosphere, exert on its walls equivalent force vectors, from inside to outside, and from outside to inside (same area, same pressure, therefore, same forces) (-Fig. 4). If we remove the internal pressure from the container, we will establish the vacuum (-Fig. 5). In the absence of pressure in its interior, external forces, caused by the still existing atmospheric pressure, will overwhelm the stability of the object itself, making it easy to be crushed, like a plastic bottle or a metal can.

The presence of force vectors caused by the atmospheric pressure are extremely powerful and, inside the skull, they

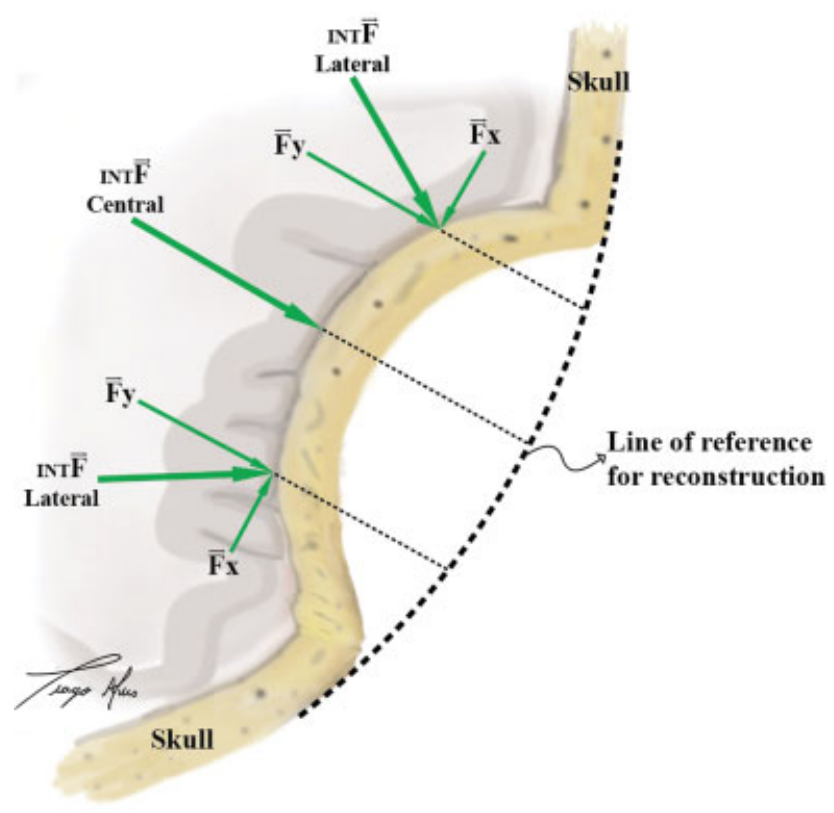

Fig. 4 Force vectors on the skull.

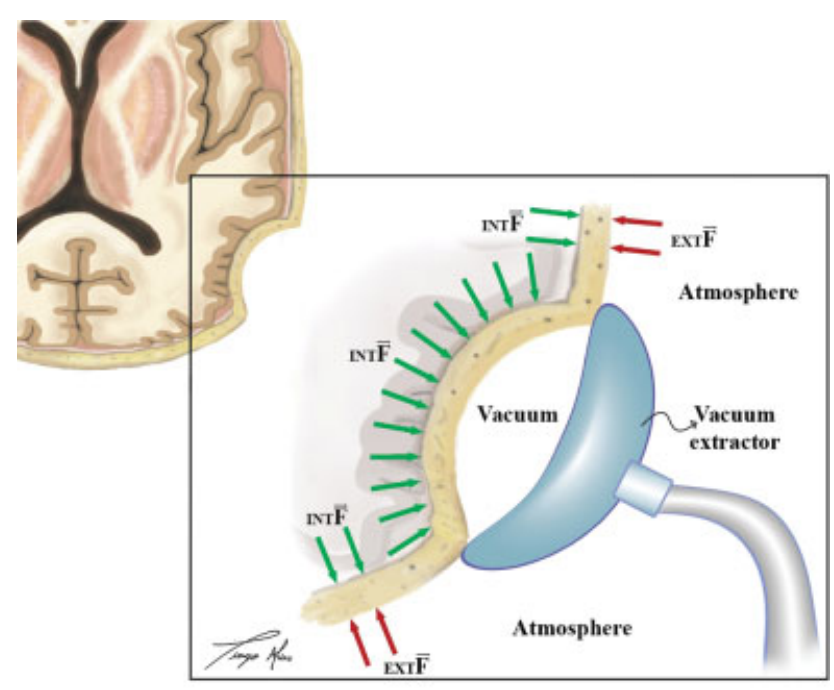

Fig. 5 Vacuum suction effect on force vectors.

can overlap the resistance of its vault, in the absence or in a great reduction of external force vectors, a phenomenon established by the reduction of the pressure on the vacuum suction device (vacuum setting or pressure reduction). As shown in the - Fig. 5, the internal pressure around the lesion is the same, and the magnitude of the forces acting on each unit of area will be equal at all points of contact. This is the rationale that justifies why the vacuum suction therapy is more homogeneous than a conventional manual surgical intervention. $^{15}$

Analyzing - Fig. 4, one can notice the action of three force vectors on the skullcap, in symmetrical and central positions to the lesion. It is noted that, by decomposing the lateral symmetrical forces, the components that are in the direction of the central force are responsible for reconstituting the cranial box back to its shape, prior to the deformation. Each component of the lateral internal forces in this direction (Fy) has, in the least deformed part, a magnitude smaller than that of the central force, corroborating the presumption that the vacuum suction is a smoother and more homogeneous procedure than the conventional ones.

\section{Discussion - Surgical versus Nonsurgical Treatment}

Although morbidity and mortality associated with surgical treatment is small, all patients undergoing this treatment modality are at risk, ranging from local complications (infections, hematomas) to death. Other disadvantages are the prolongation of hospitalization, in all its medical, social and economic aspects, and the anesthetic risks associated with surgical treatment. ${ }^{1,13}$ These details become even more important in addressing the pediatric population, because of their greater vulnerability to the possible complications associated to the procedure. On account of the above, the possibility of conservative and noninvasive treatments has become an increasingly frequent reality. ${ }^{16}$ 
In newborns, the fact that there is continuous brain growth during development, positively contributes to skull remodeling and, over the years, there is a tendency to attenuation of the depressed area. As ping-pong fractures are more frequent in this population, they may not require surgery during their treatment. ${ }^{4,17,18}$

Several less invasive modalities of treatment have been proposed over the years, in a continuous process of updating and inventing new techniques. One is the correction of the bone depression with the use of vacuum suction. The technique was first described in the literature in $1985 .^{1,12,19}$ This procedure has the advantages of its efficiency, practicality and safety. Moreover, it avoids complications associated with the anesthetic procedure and those inherent to a craniotomy or trepanation during invasive approaches. ${ }^{8,13}$ The proposed technique uses the principle of local negative pressure establishment, with traction of the affected bone segment to its previous position, and its main object of treatment is focused on ping pong fractures. Although directed predominantly to the pediatric population (especially $<2$ years old), some authors have already been successful in treating older individuals. The greatest extreme ever reported in the literature was the treatment of a depressed fracture of a 17-year-old girl. 8,13

The procedure is performed briefly and without the need for general anesthesia. Using appropriate equipment to create a negative pressure gradient, it is attached to the patient's scalp surface, on the topography of the bone defect, and is performed for only a few seconds, with light traction over it, until adequate clinical results are evident (reduction of bone and soft tissue retraction). The use of obstetric vacuum extractors and milk suction pumps for this purpose has been reported in the literature. ${ }^{13,20}$

The complications associated with the procedure reported in the literature are minimal, and are restricted to local complications, such as bruises and subgaleal edema, which resolve spontaneously. ${ }^{3}$ However, attention should be paid to the possibility of more serious lesions, such as intracranial hematomas, that may develop after traction of the bone board and adjacent structures. Radiological control (head CT scan) after the procedure may help in the detection of incipient complications. It is also of great importance that the attending physician pay attention to the accurate diagnosis of the type of fracture and the possibility of associated intracranial injuries. The presence of complications such as dural laceration, subdural and epidural hematomas, and open depressed fractures still deserve standard surgical treatment, to achieve better outcomes for the patient. ${ }^{13,14}$

\section{Conclusion}

The use of vacuum suction for the treatment of depressed skull fractures has proven to be an important tool for the neurosurgeon, especially when it comes to the pediatric population. The low rate of associated complications, the absence of the need to subject the patient to surgical stress and all its deleterious effects, and the reduction of procedure-related costs, confirm the excellence of this treatment method, as long as it is well indicated. The possibility of creating specific protocols for the management of depressed fractures, including this nontraditional method of treatment, may be a convenient reality in the future.

Conflict of Interests

The authors have no conflict of interests to declare.

\section{References}

1 Johnston JM, Park TS. Depressed skull fracture. J Neurosurg 2006; 105(06):515-516, author reply 516

2 Hossain MZ, Mondle MS, Hoque MM. Depressed skull fracture: Outcome of surgical treatment. TAJ 2008;21:140-146

3 Geisler FH, Rodriguez E, Manson PN. Traumatic Skull and Facial Fractures. In: ELLENBOGEN, Richard G., ABDULRAUF, Saleem I., SEKHAR, Laligam N. Principles of Neurological Surgery. 3. ed Philadelphia: Elsevier Saunders; 2012. Cap. 22. 3-783

4 Steinbok P, Flodmark O, Martens D, Germann ET. Management of simple depressed skull fractures in children. J Neurosurg 1987;66 (04):506-510

5 Zalatimo O, Ranasinghe M, Dias M, Iantosca M. Treatment of depressed skull fractures in neonates using percutaneous microscrew elevation. J Neurosurg Pediatr 2012;9(06):676-679

6 Tan KL. Elevation of congenital depressed fractures of the skull by the vacuum extractor. Acta Paediatr Scand 1974;63(04):562-564

7 Heary RF, Hunt CD, Krieger AJ, Schulder M, Vaid C. Nonsurgical treatment of compound depressed skull fractures. J Trauma 1993; 35(03):441-447

8 de Paul Djientcheu V, Njamnshi AK, Ongolo-Zogo P, Ako S, Essomba A, Sosso MA. Depressed skull fractures in children: Treatment using an obstetrical vacuum extractor. Pediatr Neurosurg 2006;42(05):273-276

9 Pollak L, Raziel A, Ariely S, Schiffer J. Revival of non-surgical management of neonatal depressed skull fractures. J Paediatr Child Health 1999;35(01):96-97

10 Alexander E Jr, Davis CH Jr. Intra-uterine fracture of the infant's skull. J Neurosurg 1969;30(04):446-454

11 Preston D, Jackson S, Gandhi S. Non-traumatic depressed skull fracture in a neonate or 'ping pong' fracture. Case Reports 2015; $181: 1-4$

12 Dharmaraj ST, Embleton ND, Jenkins A, Jones G. Depressed skull fracture in a newborn baby. Arch Dis Child Fetal Neonatal Ed 2009;94(02):F137

13 Kim YJ, Lee SK, Cho MK, Kim YJ. Elevation of depressed skull fracture with a cup of breast pump and a suction generator : a case report in technical aspects. J Korean Neurosurg Soc 2007;42(04): 346-348

14 Miller JD, Jennett WB. Complications of depressed skull fracture. Lancet 1968;2(7576):991-995

15 Fox RW, Mcdonald AT. Fluid Statics. In: FOX, Robert W, MCDONALD, Alan T. Introduction to Fluid Mechanics. 5. ed New Jersey: John Wiley \& Sons; 1998. Cap. 3. 44-48

16 Curry DJ, Frim DM. Delayed repair of open depressed skull fracture. Pediatr Neurosurg 1999;31(06):294-297

17 Saunders BS, Lazoritz S, McArtor RD, Marshall P, Bason WM. Depressed skull fracture in the neonate. Report of three cases. J Neurosurg 1979;50(04):512-514

18 Loeser JD, Kilburn HL, Jolley T. Management of depressed skull fracture in the newborn. J Neurosurg 1976;44(01):62-64

19 Wu CM, Hung KL, Chen TH. [A case report of depressed skull fracture of the newborn treated with a vacuum extractor]. Taiwan Yi Xue Hui Za Zhi 1985;84(02):270-275

20 Hung KL, Liao HT, Huang JS. Rational management of simple depressed skull fractures in infants. J Neurosurg 2005;103(01): 69-72 